\author{
N. O. Kniazieva ${ }^{1}$, S. V. Shestopalov ${ }^{2}$ \\ Odessa National Academy of Food Technologies, 112 Kanatnaya str., Odessa, 65039, Ukraine \\ 1e-mail: knyazeva@ukr.net, http://orcid.org/0000-0002-1523-6775 \\ 2e-mail: shestopalov_s@mail.ru, http://orcid.org/0000-0001-8941-4610
}

\title{
COMPLEX QUALITY CRITERION OF CONTROL OF THE INTELLECTUAL SERVICES PROVISION IN NGN
}

The paper is dedicated to intellectual services provision control quality comparison by the intellectual superstructures with centralized and decentralized control principles in NGN. The necessity of three parties interests consideration, namely: service providers, network equipment suppliers and network users is pointed out. The method of complex quality criterion formation is proposed.

Keywords : NGN; Intellectual Superstructure; Intellectual Services; Quality Criterion; Weighting Coefficients.

This work is licensed under the Creative Commons Attribution International License (CC BY). http://creativecommons.org/licenses/by/4.0/

\section{INTRODUCTION}

Recently in the world's developed countries there is a tendency of expenses growth on the next generation networks control systems development and implementation. And most part of the investments is directed to the service control systems building. Nowadays every operator except the basic services also provides a specific set of so-called intellectual services services that can be provided by intellectual superstructure of next generation network (NGN). These services include "smart office", "short set", "black and white lists" and many others. The variety of intelligent services increases day-by-day, so does the demand for them. In such conditions the intellectual superstructure with centralized control principle (ISCCP), which is used in existing NGN, would not be always able to perform its functions properly. A problem caused by insufficient bandwidth of the signaling network and limited capacity of the service control centers may arise. It should be noted, moreover, that there are services that do not permit execution delays. Besides, certain types of services are not intended for centralized performance according to their properties, for example, a service that prohibits a part of the incoming calls according to certain criterion. These criteria may change depending on a subscriber condition. Limitation of bandwidth of common channel signaling system SS7 and individual character of criterion, which should be used for the call provision, can result in the need to implement intelligent services through other control principles, i.e. it may be appropriate to use the intellectual superstructure with decentralized control principle (ISDCP).
Selection of the control principle raises the question regarding to the intellectual services provision control quality by intellectual superstructures with centralized and decentralized control principles. The degree of satisfaction of users' expectations and requirements to the quality of service evaluates on the basis of the control quality parameters that are used. The control quality evaluation should be performed on the basis of both the service quality indicators, set out in the ITU recommendations, and stated and implied needs of the user of the service. Thus, the task of evaluating the quality of provided intellectual services should be resolved on the basis of a comprehensive and systematic approach.

According to the ITU-T Y.1541 quality of service provision is assessed by three indicators [2]:

Speed is one of the most important indicator that characterizes the provision quality of the majority of intellectual services. Speed indicator is determined by the time interval that is used to perform the function.

Accuracy and reliability are the characteristics of consumer service properties that reveal the service suitability.

Reliability is the property of communication equipment to provide quality services.

Turning to the NGN terminology based on [2] it can be said that the service provision control quality depends on such network parameters as: IPTD (IP Packet Transfer Delay with control information), IPDV (IP packet delay variation), IPLR (IP packet loss ratio) и IPER (IP packet error ratio).

The works devoted to evaluating the effectiveness of intelligent services control $[1,3,4]$ are mostly consider 
technical indicators in accordance with the requirements to network quality indicators for services, based on IP [2]. However, as already mentioned, based on current ITU recommendations [5], the telecommunication service assessment should take into account the degree of users' satisfaction with service quality. In addition to already mentioned indicators, some other indicators that significantly affect the quality of the intellectual services provided to consumers are defined in this paper.

On the basis of the proposed indicators the resulting complex criterion was formed, that allows to compare ISCCP and ISDCP control quality.

\section{COMPLEX QUALITY CRITERION}

According to the Recommendations ITU-T I.380/ Y.1541, the NGN quality functioning determination should be based on the formation of such indicators as:

- packet transfer delay;

- packet delay variation (jitter);

- packet loss ratio;

- packet error ratio.

However, let us not forget that NGN combines the interests of three parties: service providers, equipment providers, network users, enabling fast and efficient provision of intellectual services. The user can switch on or switch off the service by himself, not waiting until the provider makes it. In this case, the user controls the service costs paying only for the time of use. This approach allows the user to save money. This, in turn, makes the services more attractive, so the demand for them rises, and thanks to that finally rises the profit of the service providers. The need for equipment also increases, and this respectively promotes the profit growth of equipment providers. As we can see, the interests of three parties are satisfied.

The intellectual services provision control quality, consequently, should be evaluated considering all participants of the process points of view. The intellectual services provision quality value will have its own significance for each participant.

According to the Recommendation ITU-T E800 (09/2008), the quality of service (QoS) is determined as totality of telecommunication service characteristics that bear on its ability to satisfy stated and implied service user needs.

There is a parallel concept of quality of experience (QoSE) - the level of quality that users believe they have experienced.

The indicators of network performance (NP), in particular, the intellectual superstructure work quality indicators characterize the ability of network or its part to provide functions connected with the intellectual services provision to the users and these services control. It is obvious, that intellectual services provision control quality for each participant of the process has its own context, though the corresponding values are interrelated.
After all, high-quality functioning of the intellectual superstructure equipment (software switches, servers of services) will make it easy to implement the service logic and able control the intellectual services. This, in turn, will improve the service quality in users terms.

Thus, in forming the complex quality criterion of intellectual services provision control using different control principles - centralized and decentralized - in this paper, on the basis of conducted researches, it is proposed to consider the participation of three parties - service providers, equipment suppliers, network users.

To obtain the complex control quality criterion it is proposed a methodical approach, consisting of the following sequence of steps:

1. Determination of the influence degree of each participant of the process on the value of the complex control quality criterion.

2. Definition of sub-criteria for each participant of the process.

3. Formation of weighting coefficients for subcriteria.

4. Assessment of the value achieved by each subcriterion.

5. Determination of the resulting scores for each participant of the process.

6. Determination of the complex control quality criteria.

Let us consider the implementation of steps of the proposed methodical approach for assessment the quality of control the intelligent services provision from the perspective of all participants of the process.

Step 1. Determination of the influence degree of each participant of the process on the complex control quality criterion. Value

To take into account the degree of importance of each participant of the process - namely, the degree of his impact on the result - the complex control quality criterion of the intellectual services provision - by the method of expert evaluations, to each $i$-th participant of the process are assigned "weights" $W_{i}$ in the accepted assessment system. If the experts conclude that the impact of all the participants on the result is equal, they set equal "weights" $W_{i}$.

Step 2. Definition of sub-criteria for each participant of the process.

For each participant of the process of forming the complex control quality criterion of the intellectual services provision - service provider, equipment supplier, network user - indicators which should be taken into account in forming the complex criterion (hereinafter let us call them sub-criteria) are determined.

From the user's viewpoint the quality of control in the provision of intellectual services can be most accurately evaluated using the value $\bar{Z}-$ the degree of users' satisfaction with the quality of received services, which is formed by combination of different elements that work independently of each other: user's equipment $\bar{E}_{u}$, 
service transport $\bar{T}_{s}$, service provision $\bar{P}_{s}$ and content creation $\bar{C}_{c}$ [8].

From the service provider's viewpoint the quality of control in the provision of intellectual services it is proposed to evaluate by the complexity of the the service logic introduction and administration $\overline{S t}$ and by the quantity of successfully provided intellectual services $\bar{S}$, that will raise the demand for them. It should be noted that the complexity of the introduction of the service logic and administration $\overline{S t}$ is a sub-criterion, the achieved level of which_for ISCCP and ISDCP is set by the method of expert evaluations.

From the equipment supplier's viewpoint the quality of control evaluates by criteria, determined by the ITU-T Recommendations Y.1541 [2], namely: time of service provision $\bar{T}_{c s}$, the length of the queue, into which the request falls to be served on the server $\bar{L}$, the probability of refuse in service provision $\bar{P}_{B}$.

In addition to the specified sub-criteria, in accordance with the ITU Recommendations for future networks [9], the following indicators are proposed as sub-criteria: structural survivability $\bar{P}_{s t}$ and reliability of control systems $\bar{R}$. Additionally, it is proposed to take into account as a sub-criterion the cost of the intellectual superstructure $\bar{C}$.

Step 3. Formation of weighting coefficients for subcriteria.

To take into account the degree of importance of each participant of the process - namely, the degree of its impact on the result - the complex control quality criterion of the intellectual services provision - the weighting coefficients $K_{i j}$ are determined by the method of expert evaluations. There $j$ is a number of sub-criterion of $i$-th participant of the process (Table 1 column 2). The values of obtained weighting factors are normalized for each $j$-th participant of the process, i.e. $\sum_{i j}^{n i} K_{i j}=1 \quad(n i$ is a quantity of sub-criteria of $i$-th participant of the process; the value $n i$ can be different for each $i$-th participant).

Step 4. Assessment of the value achieved by each sub-criterion.

For each sub-criterion of each participant of the process the maximum or minimum (depending on the subcriterion type) acceptable and current values (in appropriate units or in scores) are determined.

Find the relative scores $O_{i j}$ for each sub-criterion. Relative score is formed as a product of ratio of current value of indicator and its maximum acceptable value (or based on the ratio of minimum acceptable value and current indicator value) and a weighting factor $K_{i j}$ of the sub-criterion determined at step 3 . The method of calculation of each relative score is shown in Table 1 (column 5 is for ISCCP and column 8 is for ISDCP). Column 3 includes maximal or minimal acceptable values of the quality sub-criteria for further definition of relative scores $O_{i j}$. Column 4 contains the current values of the quality sub-criteria. Columns 6 and 7 are filled similarly for ISDCP.

Step 5. Determination of the resulting scores for each participant of the process.

In this step the resulting value is determined. It is an overall weighted score of all the sub-criteria for each $i$-th participant of the process:

$$
A_{i} \sum_{i}^{n i} O_{i j} .
$$

Here $O_{i j}$ is the relative score obtained for $j$-th subcriterion of $i$-th participant of the process and determined on step 4;

$i$ is a number of the participant of the process, $i=\overline{1, m} ; m$ is a quantity of the participants;

$j$ is a number of sub-criterion of $i$-th participant of the process, $j=\overline{1, n i}, n i$ is a quantity of the sub-criteria of $i$-th participant of the process; criteria.

Step 6. Determination of the complex control quality

Determine the value of the resulting complex quality criterion for intellectual superstructures with centralized and decentralized control principles. Then, having the value of the resulting score $A_{i}$ (1) for each $i$-th participant of the process, let us determine the complex quality criterion $K$ for intellectual superstructures with centralized and decentralized control principles considering interests of all participants of the process:

$$
K=\sum_{i=1}^{m} A_{i} W_{i}
$$

The obtained value of the complex quality criterion $K$ (2) for the intellectual superstructure with centralized and decentralized control principles demonstrates the feasibility of their application for controlling the provision of intellectual services.

Table 1 presents a method of calculation the relative valuations, as well as the total weighted assessment of all sub-criteria for each $i$-th participant of the $A i$ process at the following initial data:

- quantity of participants of the process $m=3$;

- quantity of sub-criteria of the first participant of the process $n 1=4$;

- quantity of sub-criteria of the second participant of the process $n 2=2$;

- quantity of sub-criteria of the third participant of the process $n 3=6$.

Complex quality criterion $K$ calculates on the basis of the expression (2).

\section{CONCLUSION}

Complex control quality criterion of the intellectual services provision, which takes into account interests of three parties: service providers, network users, equipment providers is presented in the paper. The subcriteria and the method of assessing the impact of each 
Table 1 - List of the value of control quality in provision of intellectual services by superstructure NGN

\begin{tabular}{|c|c|c|c|c|c|c|c|}
\hline \multirow[b]{3}{*}{$\begin{array}{c}\text { Quality } \\
\text { subcriterion }\end{array}$} & \multirow{3}{*}{$\begin{array}{l}\text { Weight of } \\
\text { a } \\
\text { subcriteri } \\
\text { on }\end{array}$} & \multicolumn{6}{|c|}{ Intelligent superstructure that analyzes } \\
\hline & & \multicolumn{3}{|c|}{ ISCMP } & \multicolumn{3}{|c|}{ ISDMP } \\
\hline & & $\begin{array}{l}\text { Maximal or } \\
\text { minimal } \\
\text { admissible } \\
\text { value }\end{array}$ & $\begin{array}{l}\text { The } \\
\text { resulting } \\
\text { value }\end{array}$ & $\begin{array}{l}\text { Evaluation } \\
\qquad\left(O_{i j}\right)\end{array}$ & $\begin{array}{l}\text { Maximal or } \\
\text { minimal } \\
\text { admissible } \\
\text { value }\end{array}$ & $\begin{array}{l}\text { The } \\
\text { resultin } \\
\text { g value }\end{array}$ & $\begin{array}{l}\text { Evaluation } \\
\qquad\left(O_{i j}\right)\end{array}$ \\
\hline 1 & 2 & 3 & 4 & 5 & 6 & 7 & 8 \\
\hline \multicolumn{8}{|c|}{ I. From the user's viewpoint } \\
\hline $\begin{array}{l}\text { 1.Customer } \\
\text { Equipment } \bar{E}_{u}\end{array}$ & $K_{11}$ & $\bar{E}_{u_{\mathrm{ISCCP}}}(\max )$ & $\bar{E}_{u_{\mathrm{ISCCP}}}$ & $\frac{K_{11} \bar{E}_{u_{\mathrm{ISCCP}}}}{\bar{E}_{u_{\mathrm{ISCCP}}}(\max )}$ & $\bar{E}_{u_{\mathrm{ISDCP}}}(\max )$ & $\bar{E}_{u \mathrm{ISDCP}}$ & $\frac{K_{11} \bar{E}_{u_{\mathrm{ISDCP}}}}{\bar{E}_{u_{\mathrm{ISDCP}}}(\max )}$ \\
\hline $\begin{array}{l}\text { 2. Service } \\
\text { Transport } \bar{T}_{s}\end{array}$ & $K_{12}$ & $\bar{T}_{s_{\text {ISCCP }}}(\max )$ & $\bar{T}_{s_{\text {ISCCP }}}$ & $\frac{K_{12} \bar{T}_{s_{\text {ISCCP }}}}{\bar{T}_{s_{\text {ISCCP }}}(\max )}$ & $\bar{T}_{s_{\text {ISDCP }}}(\max )$ & $\bar{T}_{s \mathrm{ISDCP}}$ & $\frac{K_{12} \bar{T}_{s_{\mathrm{ISDCP}}}}{\bar{T}_{s_{\mathrm{ISDCP}}}(\max )}$ \\
\hline $\begin{array}{l}\text { 3. Service } \\
\text { Provision }\end{array}$ & $K_{13}$ & $\bar{P}_{s \text { ISCCP }}(\max )$ & $\bar{P}_{s_{\mathrm{ISCCP}}}$ & $\frac{K_{13} \bar{P}_{s_{\text {ISCCP }}}}{\bar{P}_{s_{\text {ISCCP }}}(\max )}$ & $\bar{P}_{s \text { ISDCP }}(\max )$ & $\bar{P}_{s_{\text {ISDCP }}}$ & $\frac{K_{13} \bar{P}_{s_{\text {ISDCP }}}}{\bar{P}_{s_{\text {ISDCP }}}(\max )}$ \\
\hline $\begin{array}{l}\text { 4.Content } \\
\text { Creation } \bar{C}_{c}\end{array}$ & $K_{14}$ & $\bar{C}_{c_{\text {ISCCP }}}(\max )$ & $\bar{C}_{c_{\text {ISCCP }}}$ & $\frac{K_{14} \bar{C}_{c_{\text {ISCMP }}}}{\bar{C}_{c_{\text {ISCCP }}}(\max )}$ & $\bar{C}_{c_{\text {ISDCP }}}(\max )$ & $\bar{C}_{c \text { ISDCP }}$ & $\frac{K_{14} \bar{C}_{c_{\text {ISDCP }}}}{\bar{C}_{c_{\text {ISDCP }}}(\max )}$ \\
\hline Total & $\sum_{j=1}^{4} K_{i j}=1$ & & & $\sum_{j=1}^{4} O_{i j}$ & & & $\sum_{j=1}^{4} O_{i j}$ \\
\hline \multicolumn{8}{|c|}{ II. From the service provider's viewpoint } \\
\hline $\begin{array}{l}\text { 1.The } \\
\text { complexity of } \\
\text { the logic of } \\
\text { implementation } \\
\text { and control of } \\
\text { the service } \overline{S t}\end{array}$ & $K_{21}$ & $\overline{S t}_{\mathrm{ISCCP}}(\min )$ & $\overline{S t}_{\mathrm{ISCCP}}$ & $\frac{K_{21} \overline{S t}_{\mathrm{ISCCP}}(\mathrm{min})}{\overline{S t}_{\mathrm{ISCCP}}}$ & $\overline{S t}_{\mathrm{ISDCP}}(\mathrm{min})$ & $\overline{S t}_{\mathrm{ISDCP}}$ & $\frac{K_{21} \overline{S t}_{\mathrm{ISDCP}}(\mathrm{min})}{\overline{S t}_{\mathrm{ISDCP}}}$ \\
\hline $\begin{array}{l}\text { 2. The number } \\
\text { of successfully } \\
\text { provided } \\
\text { intellectual } \\
\text { services } \bar{S}\end{array}$ & $K_{22}$ & $\bar{S}_{I S C C P}(\max )$ & $\bar{S}_{\text {ISCCP }}$ & $\frac{K_{22} \bar{S}_{\text {ISCCP }}}{\bar{S}_{\text {ISCCP }}(\max )}$ & $\bar{S}_{\text {ISDCP }}(\max )$ & $\bar{S}_{\text {ISDCP }}$ & $\frac{K_{22} \bar{S}_{\text {ISDCP }}}{\bar{S}_{\text {ISDCP }}(\max )}$ \\
\hline Total & $\sum_{j=1}^{2} K_{i j}=1$ & & & $\sum_{j=1}^{2} O_{i j}$ & & & $\sum_{j=1}^{2} O_{i j}$ \\
\hline \multicolumn{8}{|c|}{ III. From equipment supplier's viewpoint } \\
\hline $\begin{array}{l}\text { 1.Time for } \\
\text { Service } \\
\text { Provision } \bar{T}_{c s}\end{array}$ & $K_{31}$ & $\bar{T}_{c s_{\text {ISCCP }}}(\min )$ & $\bar{T}_{c s \text { ISCCP }}$ & $\frac{K_{31} \bar{T}_{c s_{\mathrm{ISCCP}}(\mathrm{min})}}{\bar{T}_{c s_{\mathrm{ISCCP}}}}$ & $\bar{T}_{c s_{\text {ISDCP }}}(\min )$ & $\bar{T}_{c s_{\text {ISDCP }}}$ & $\frac{K_{31} \bar{T}_{c s \mathrm{ISDCP}}(\mathrm{min}}{\bar{T}_{c s \mathrm{ISDCP}}}$ \\
\hline $\begin{array}{l}\text { 2.Queue } \\
\text { Length } \bar{L}\end{array}$ & $K_{32}$ & $\bar{L}_{\mathrm{ISCCP}}(\min )$ & $\bar{L}_{\text {ISCCP }}$ & $\frac{K_{32} \bar{L}_{\mathrm{ISCCP}}(\mathrm{min})}{\bar{L}_{\mathrm{ISCCP}}}$ & $\bar{L}_{\mathrm{ISDCP}}(\min )$ & $\bar{L}_{\text {ISDCP }}$ & $\frac{K_{32} \bar{L}_{\text {ISDCP }}(\mathrm{min})}{\bar{L}_{\mathrm{ISDCP}}}$ \\
\hline $\begin{array}{l}\text { 3.The } \\
\text { probability of } \\
\text { Refusing in } \\
\text { Service Provisi } \\
\text { on } \bar{P}_{B}\end{array}$ & $K_{33}$ & $\bar{P}_{B_{\text {ISCCP }}}(\min )$ & $\bar{P}_{B \text { ISCCP }}$ & $\frac{K_{33} \bar{P}_{B_{\text {ISCCP }}}(\mathrm{min})}{\bar{P}_{B_{\mathrm{ISCCP}}}}$ & $\bar{P}_{B_{\text {ISDCP }}}(\min )$ & $\bar{P}_{B \text { ISDCP }}$ & $\frac{K_{33} \bar{P}_{B_{\mathrm{ISDCP}}}(\mathrm{m} \mid \mathrm{n})}{\bar{P}_{B_{\mathrm{ISDCP}}}}$ \\
\hline
\end{tabular}


Table 1 - Continue

\begin{tabular}{|c|c|c|c|c|c|c|c|}
\hline $\begin{array}{l}\text { 4. Structural } \\
\text { survivability } \\
\bar{P}_{s t}\end{array}$ & $K_{34}$ & $\bar{P}_{s t \text { ISCCP }}(\max )$ & $\bar{P}_{s t \text { ISCCP }}$ & $\frac{K_{34} \bar{P}_{s t \text { ISCCP }}}{\bar{P}_{s t}{ }_{\text {ISCCP }}(\max )}$ & $\bar{P}_{s t \text { ISDCP }}(\max )$ & $\bar{P}_{s t} \mathrm{ISDCP}$ & $\frac{K_{34} \bar{P}_{s t} \text { ISDCP }}{\bar{P}_{s t}{ }_{\mathrm{ISDCP}}(\max )}$ \\
\hline 5.Reliability $\bar{R}$ & $K_{35}$ & $\bar{R}_{I C C P}(\max )$ & $\bar{R}_{\mathrm{ISCCP}}$ & $\frac{K_{35} \bar{R}_{\mathrm{ISCCP}}}{\bar{R}_{\mathrm{ISCCP}}(\max )}$ & $\bar{R}_{\mathrm{ISDCP}}(\max )$ & $\bar{R}_{\mathrm{ISDCP}}$ & $\frac{K_{35} \bar{R}_{\mathrm{ISDCP}}}{\bar{R}_{\mathrm{ISDCP}}(\max )}$ \\
\hline $\begin{array}{l}\text { 6.Cost of } \\
\text { intellectual } \\
\text { superstructure } \\
\bar{C}\end{array}$ & $K_{36}$ & $\bar{C}_{\text {ISCCP }}(\min )$ & $\bar{C}_{\text {ISCCP }}$ & $\frac{K_{36} \bar{C}_{\mathrm{ISCCP}}(\mathrm{min})}{\bar{C}_{\mathrm{ISCCP}}}$ & $\bar{C}_{\mathrm{ISDCP}}(\min )$ & $\bar{C}_{\mathrm{ISDCP}}$ & $\frac{K_{36} \bar{C}_{\text {ISDCP }}(\mathrm{min}}{\bar{C}_{\mathrm{ISDCP}}}$ \\
\hline Total & $\sum_{j=1}^{6} K_{i j}=1$ & & & $\sum_{j=1}^{6} O_{i j}$ & & & $\sum_{j=1}^{6} O_{i j}$ \\
\hline
\end{tabular}

participant of the process and each sub-criterion on the result - complex control quality criterion of the intellectual services provision are determined. The value of the complex criterion allows us to compare the quality of control in the intelligent services provision by ISCCP and ISDCP. Proposed methodical approach allows us to define the complex control quality criterion and can be used at the stage of the next generation networks design, since it helps to choose the creation principle of the intellectual superstructure. As a further research, it is planned to develop analytical and simulation models of ISCCP and ISDCP considering the self-similarity of traffic.

\section{REFERENCES}

1. Knyazeva, N. O. Shestopalov, S. V. (2010). Pídvyshchennia yakostí upravlínnia poslugami pri zastosuvanní detsentralízovanoi systemy upravlínnia. Visnik DUÍKT, 8(1), 21-28 (in Ukrainian).

2. Trebovaniya k setevym pokazatelyam kachestva dlya sluzhb, osnovannykh na protokole IP: MSE-T. - Y.1541. [Pereizd. Fev. 2007 s izm.]. Zheneva, 2007, 43 p.

3. Steklov V. K., Berkman L. N. (2002). Proiektuvannia telekomuníkatsíynikh merezh. K.: Tekhníka, 792 p. (in Ukrainian).
4. Shestopalov S. V. (2013). Kachestvo upravleniia intellektual'nymi uslugami $\mathrm{v}$ setyakh sleduiushchego pokoleniia. Information Models and Analyses, vol.2, iss. 3, 262-274 (in Russian).

5. ITU-T Recommendation E.802 - Framework and methodologies for the determination and application of QoS parameters, Geneva, 2007.

6. ITU-T Recommendation Y.1540 - Internet protocol data communication service - IP packet transfer and availability performance parameters. Approoved in 2007, $46 \mathrm{p}$.

7. ITU-R Recommendation E.800 - Quality of telecommunication services: concepts, models, objectives and dependability planning - Terms and definitions, related to Quality of Services and network performance including dependability. Approoved in 2008, 30 p.

8. Knyazeva N. A. Kal'chenko A. S. (2013). Otsenka kachestva uslug svyazi s pozitsiy udovletvorennosti potrebiteley. Science and Education a New Dimension: Natural and Technical Science, vol. 8, 156-161 (in Russian).

9. Recommendation ITU-T Y.3001 Future Networks: Objectives and Design Goals, ITU-T Study Group. Approoved in 2011, 26 p. 


\title{
Н. О. Князєва
}

Одеська національна академія харчових технологій, вул. Канатна 112, Одеса, 65082, Україна

1e-mail: knyazeva@ukr.net, http://orcid.org/0000-0002-1523-6775

2e-mail: shestopalov_s@mail.ru, http://orcid.org/0000-0001-8941-4610

\section{КОМПЛЕКСНИЙ КРИТЕРІЙ ЯКОСТІ УПРАВЛІННЯ НАДАННЯМ ІНТЕЛЛЕКТУАЛЬНОГО CEPBICУ B NGN}

\begin{abstract}
Стаття присвячена порівнянню якості управління наданням інтелектуального сервіса інтелектуальними надбудовами з централізованим і децентралізованих принципами управління 8 NGN. Наголошується на необхідності врахування інтересів трьох сторін: постачальників послуг, постачальників обладнання, користувачів мережі. Запропоновано метод формування комплексного критерію якості управління наданням інтелектуального сервіса. Визначена міра впливу кожного учасника на значення комплексного критерію якості. Запропоновані підкритерії для кожного учасника процесу. Сформовані вагові коефіцієнти для кожного підкритерію. Визначена оцінка для кожного підкритерію. Визначена результуюча оцінка для кожного учасника прочесу управління наданням інтелектуального сервіса. Визначено комплексний критерій якості. Запропонований комплексний критерій дозволяе порівняти якість управління наданням інтелектуальних послуг інтелектуальними надбудовами з централізованим та децентралізованим принцииами управління.
\end{abstract}

Ключові слова: $N G N$; інтелектуальний сервіс; інтелектуальна надбудова; критерій якості; вагові коефіиієнти. 